\title{
South American Species of Stridulivelia (Hemiptera: Heteroptera: Veliidae): Identification Key, Diagnoses, Illustrations, and Updated Distribution
}

Author(s): Carla Fernanda Burguez Floriano, Felipe Ferraz Figueiredo Moreira, and Pitágoras Da Conceição Bispo

Source: Proceedings of the Entomological Society of Washington, 119(1):24-46.

Published By: Entomological Society of Washington

DOI: http://dx.doi.org/10.4289/0013-8797.119.1.24

URL: http://www.bioone.org/doi/full/10.4289/0013-8797.119.1.24

BioOne (www.bioone.org) is a nonprofit, online aggregation of core research in the biological, ecological, and environmental sciences. BioOne provides a sustainable online platform for over 170 journals and books published by nonprofit societies, associations, museums, institutions, and presses.

Your use of this PDF, the BioOne Web site, and all posted and associated content indicates your acceptance of BioOne's Terms of Use, available at www.bioone.org/page/ terms of use.

Usage of BioOne content is strictly limited to personal, educational, and non-commercial use. Commercial inquiries or rights and permissions requests should be directed to the individual publisher as copyright holder. 
PROC. ENTOMOL. SOC. WASH.

119(1), 2017, pp. 24-46

\title{
SOUTH AMERICAN SPECIES OF STRIDULIVELIA (HEMIPTERA: HETEROPTERA: VELIIDAE): IDENTIFICATION KEY, DIAGNOSES, ILLUSTRATIONS, AND UPDATED DISTRIBUTION
}

\author{
Carla Fernanda Burguez Floriano, Felipe Ferraz Figueiredo Moreira, and \\ Pitágoras da Conceição Bispo
}

(CFBF, PCB) Department of Biological Sciences, Universidade Estadual Paulista, Assis, SP, Brazil. (CFBF) Department of Biological Sciences, Universidade de São Paulo, Ribeirão Preto, SP, Brazil. carlla.floriano@gmail.com. (FFFM) Laboratório de Biodiversidade Entomológica, Instituto Oswaldo Cruz, Fundação Oswaldo Cruz, Rio de Janeiro, RJ, Brazil

Abstract.-The genus Stridulivelia Hungerford (Heteroptera: Veliidae: Veliinae) is composed by 15 species, which are divided into the subgenera Stridulivelia s.str. Hungerford and Aenictovelia Polhemus. The nominal subgenus includes ten species restricted to South America, ranging from Colombia to Argentina. The other subgenus contains five primarily Mesoamerican species, one of which extends its distribution into northern South America. An updated identification key, diagnoses, notes, and illustrations of all South American species are provided.

Key Words: Aquatic insects, Gerromorpha, Stridulivelia (Aenictovelia), Stridulivelia (Stridulivelia), taxonomy, Veliinae

DOI: 10.4289/0013-8797.119.1.24

The genus Stridulivelia Hungerford (Heteroptera: Veliidae: Veliinae) is composed by 15 species, which are characterized by having the sides of thorax with several glabrous, depressed structures and at least the first two visible abdominal segments with transverse lateral sulci (Hungerford 1929; Polhemus and Spangler 1995; Rodrigues et al. 2014). It is divided into two subgenera: Stridulivelia s.str. Hungerford and $S$. (Aenictovelia) Polhemus. Species of Stridulivelia s.str. have stridulatory structures on hind femur and abdominal connexiva, whereas those of $S$. (Aenictovelia) lack stridulatory structures (Drake and Menke 1962; Polhemus 1979; Polhemus and Spangler 1995).
The nominal subgenus occurs in South America and includes ten species: S. alia (Drake); S. anta Polhemus and Spangler; S. astralis (Drake and Harris); S ayacucho Polhemus and Spangler; S. quadrispinosa (Hungerford); S. raspa (Hungerford); S. stridulata (Hungerford); S. strigosa (Hungerford); S. tersa (Drake and Harris); and $S$. transversa (Hungerford) (Polhemus and Spangler 1995). The other subgenus contains five primarily Mesoamerican species: S. cinctipes (Champion), S. epeixis (Drake and Menke), S. pueblana (Drake), $S$. secerna Polhemus and S. speciosa Polhemus and Polhemus (Drake and Menke 1962; Polhemus 1979).

The genus is widespread in South America, ranging from Colombia to 
Argentina, and individuals are usually found in streams, although they also have been recorded from lentic environments (Polhemus and Spangler 1995, Mazzucconi and Bachmann 1997, Dias-Silva et al. 2013b). They can be collected along the margins of water bodies, hidden among emergent vegetation (Nieser and Melo 1997; personal observations).

Polhemus and Spangler (1995) revised Stridulivelia s.str., described new species, and proposed an identification key. Some of the steps of the key, however, were based on the ratios between the antennomere lengths and head width or on the number of transverse lateral sulci on the abdominal segments, which are subject to variation in certain species and can cause some confusion. In the present study, we propose a new identification key based on more stable characters and provide diagnoses, illustrations and the updated geographical distribution of each species.

\section{Material AND Methods}

This study was based on the examination of dry specimens deposited in the National Museum of Natural History (NMNH), Smithsonian Institution, Washington D.C., USA. Unfortunately, males of $S$. (S.) raspa were not available and, therefore, their characters are not included in the diagnosis of the species. Photographs were taken using a Cannon EOS 5D camera and combined into multifocal images using Visionary Digital ${ }^{\circledR}$ Software. Label data are given inside quotation marks, with a reversed slash (I) separating lines on the labels and a semicolon separating labels of a specimen.

\section{Identification key to South American Stridulivelia Hungerford}

[modified from Polhemus and Spangler (1995)]
1. Stridulatory structures absent .. S. (Aenictovelia) [S. (A.) cinctipes] Stridulatory structures present on dorsum of hind femur (as in Figs. 19, 30, 53) and outer margins of abdominal connexiva (as in Figs. 23, 34) ...........S. (Stridulivelia) 2

2. Middle tarsus with three blade-like structures (modified claws and arolium, Fig. 4); male hind trochanter armed with a spur (Fig. 1) $S$. (S.) transversa Middle tarsus with narrow, falcate claws and setae-like arolia (Fig. 3); male hind trochanter unarmed or armed with only small spinules (Fig. 2)

3. Pronotal humeral angles spinose (Figs. $13,15,17,18)$ S. (S.) alia

- $\quad$ Pronotal humeral angles not spinose (as in Figs. 19, 21)

4. First four or five visible abdominal segments with transverse lateral sulci (Fig. 64) S. (S.) tersa

- First two or three visible abdominal segments with transverse lateral sulci (as in Figs. 43, 46, 56)

5. Hind femur long and slender, about $1.5 \mathrm{X}$ wider than middle femur, without a distinctly larger spine on distal $2 / 3$ of posterior margin (Fig. 53A) S. (S.) strigosa Hind femur incrassate, more than $2 \mathrm{X}$ wider than middle femur, with a spine on distal $2 /$ 3 of posterior margin distinctly larger than others (as in Figs. 39, 47)

6. Stridulatory structure on outer margin of abdominal connexiva formed by a row of widely separated knob-like denticles (as in Fig. 34)

6'. Stridulatory structure on outer margin of abdominal connexiva formed by a row of tightly packed minute pegs (Fig. 46) or a row of fine vertical ridges (as in Fig. 23) 8

7. Male genital segment I ventrally with a distinct central lobule on posterior margin (Fig. 51); paramere with rounded apex (Fig. 79); female abdominal tergite VIII with long projections, subequal to the length of the segment at midline (Fig. 50) S. (S.) stridulata 
- $\quad$ Male genital segment I ventrally at most with a central expansion, but not forming a lobule (Figs. 32, 34); paramere with acute apex (Fig. 76); female abdominal tergite VIII with short projections, about one third the length of the segment at midline (Fig. 36) S. (S.) ayacucho

8. Stridulatory structure on outer margin of abdominal connexiva formed by a row of tightly packed minute pegs (Figs. 29, 46)

...9

- $\quad$ Stridulatory structure on outer margin of abdominal connexiva formed by a row of fine vertical ridges (as in Fig. 23) .10

9. Body length $3.40-4.30 \mathrm{~mm}$; male without ventral projections on last abdominal segment (Figs. 27, 29); apically rounded paramere with anterior margin abruptly expanded before middle (Fig. 75); posterior margin of female abdominal tergite VIII straight; apex of female proctiger, in dorsal view, acute (Fig. 28) S. (S.) astralis

- Body length 4.40-4.80 mm; male with a pair of projections ventrally on last abdominal segment; apically acute paramere with anterior margin not abruptly expanded (Fig. 78); posterior margin of female abdominal tergite VIII with a notch; apex of female proctiger, in dorsal view, rounded (Figs. 44, 45)

S.(S.) raspa

10. Body length $3.90-4.50 \mathrm{~mm}$; apex of paramere acute (Fig. 74) ....... S.(S.) anta

10'. Body length $4.70-5.40 \mathrm{~mm}$; apex of paramere rounded (Fig. 77)

S. (S.) quadrispinosa

Stridulivelia (Aenictovelia) cinctipes (Champion, 1898)

(Figs. 5-11, 12, 72)

Velia cinctipes Champion, 1898: 141, 143, plate IX (description, illustration, key); Kirkaldy and Torre-Bueno 1909:
205 (distribution, list); Allee and Torvik 1927: 67 (ecology).

Velia (Stridulivelia) cinctipes: Hungerford 1929: 55-59 (subgenus placement, illustration, key); Drake and Menke 1962: 413, 415-416, plate 3 (illustration, key, records).

Stridulivelia cinctipes: Polhemus 1976: 509 (Stridulivelia elevated to genus); Alvarez and Roldán-Pérez 1983: 40, 44 (ecology, illustration); Froeschner 1999: 277 (distribution, list); Moreira et al. 2011b: 22 (distribution, list); Pacheco-Chaves et al. 2014: 185 (records).

Stridulivelia (Aenictovelia) cinctipes: Polhemus 1979: 46 (description of subgenus); Polhemus and Spangler 1995: 128, 130-131 (diagnosis, illustration, key, map, records).

Material examined.-30" $0^{\prime \prime}, 4$ 우우 (NMNH): 'Costa Rica: N. of $\backslash$ Esparzal XII. 24, 1969; CL 1264\ J.T. Polhemus.' 20"0', 2ᄋๆ (NMNH): 'Costa Rica, S. San\Isidro del General\ CL1278, XI27-1969\J.T.Polhemus.' 20"0", 3우 (NMNH): 'Panama,\El Valle\ CL1298; I-3-70\ J.T. Polhemus'. 1 ㅇ (NMNH): 'Barro Colorado\ C.Z. Panamal Feb. 68, 1939\ Carl. J. Drake'; 'CJDrake\Coll 1956'; 'Velia $\backslash$ cinctipes $\backslash$ Champ.\ Det. J. P. Polhemus.' 1 우 (NMNH): 'Colombia: Sierra\ Nevada de Santa\Marta, Pueblo Bello,I 1200 m.I April 14-15, 1968'; 'Borys Malkin' 'Velia $\backslash$ cinctipes Champ.\Det. J. T. Polhemus.' 10', 4우 (NMNH): 'Barro Coloradol C.Z. Panama\Feb.\6-8, 1939\Carl. J. Drake'; 'CJ Drakel Coll. 1956.' 10', 11우 (NMNH): 'Panama Canal\Zone 1936 Rozeboom'; 'C J Drakel Coll 1956.' 10', 2 우 (NMNH): ' Puntarenas $\backslash$ Costa Rica\} 1 6 \text { VII } 57 D R Lauck'; 'C J Drakel Coll 1956'.

Diagnosis.-Pronotal humeral angles not spinose (Figs. 5, 7, 8, 10); stridulatory structures absent; first five or six visible abdominal segments with transverse lateral 

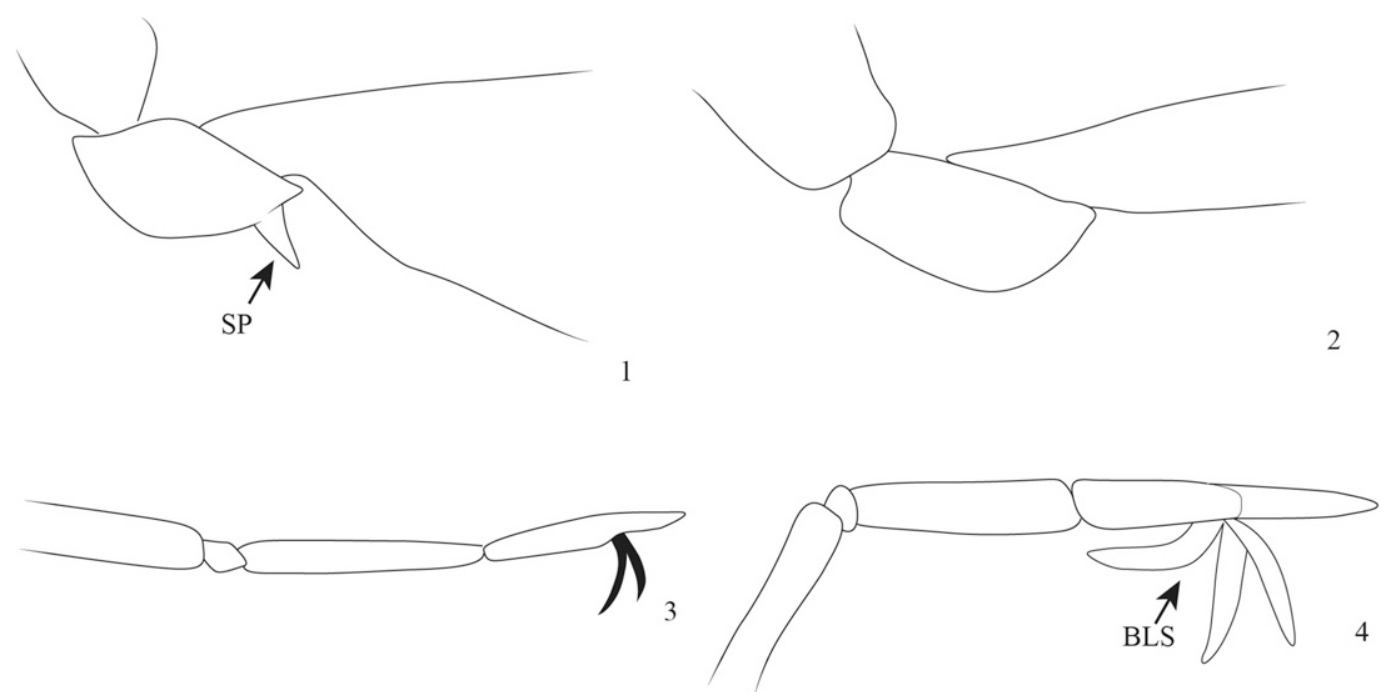

Figs. 1-4. 1, Metathoracic trochanter, S. transversa. 2, Metathoracic trochanter, S. anta. 3, Metathoracic tarsus, $S$. anta. 4, Metathoracic tarsus, S. transversa. BLS: blade-like claws; SP: spur.

sulci (Fig. 11); middle tarsus with three blade-like structures (modified claws and arolium, as in Fig. 4); male hind trochanter usually armed with a long, stout spur (Fig. 6); spur extremely variable, almost lacking in some specimens and extremely long in others; hind femur two to four times wider than middle femur, with a spine on distal $2 / 3$ of posterior margin distinctly larger than others (Figs. 5-11); last abdominal sternite of male without lateral projections (Fig. 6, 11); male genital segment I ventrally rounded (Fig. 6); male proctiger without anterocentral projection; paramere with complex shape, a strong projection on anterior margin, and apex acute (Fig. 72); female abdominal tergite VIII without projections (Fig. 10).

\section{Stridulivelia (Stridulivelia) alia \\ (Drake, 1957)}

(Figs. 13-18, 37, 73)

Velia alia Drake 1957: 115-116 (description).
Striduivelia alia: Polhemus 1976: 509 (Stridulivelia elevated to genus); Moreira et al. 2011a: 662 (records); Cunha et al. 2015: 427 (ecology).

Stridulivelia (Stridulivelia) alia: Polhemus 1979: 46 (subgenus placement); Polhemus and Spangler 1995: 128, 131, 132-134 (diagnosis, illustration, key, map, records); Moreira et al. 2011b: 22 (distribution, list).

Material examined.-10" holotype (NMNH): 'Bartica Dist.I Br. Guianal 25-V-1944' 'C J Drakel Coll 1956'; 'Holotype $\backslash$ Velia $\backslash$ alia $\backslash$ Drake'. 1 o allotype (NMNH): 'Suriname\leg. Geijskes\ sectee.l busheckeeal 7-6-1944'; 'Allotype\ Velial alia\ Drake' 'Velia\ alia $\backslash$ Allotype $\backslash$ Drake'. 80"0", 12 우 (NMNH): 'Venezuela, Amazonas $\backslash$ small stream $1 \mathrm{~km}$. N. of $\backslash$ Alto Mavaca base camp $\backslash$ $2^{\circ} 1^{\prime} 20^{\prime \prime} \mathrm{N}, 65^{\circ} 7^{\prime} 0$ '” $\backslash 228 \mathrm{~m} .22^{\circ} \mathrm{C}$ 4 Feb. 1989 CL 8006 D.A. Polhemus'. 50"0', 6 우 (NMNH): 'Brazil, Amazonas\ Igarape da Anta, Reserva Ducke, 25 km. NE of $\backslash$ Manaus, $60 \mathrm{~m} .24 .5^{\circ} \mathrm{C} . \backslash 25$ August 1989 CL $2472 \backslash$ D.A. and J.T Polhemus'. 20"0", 2 우 (NMNH): Surinam\SN 


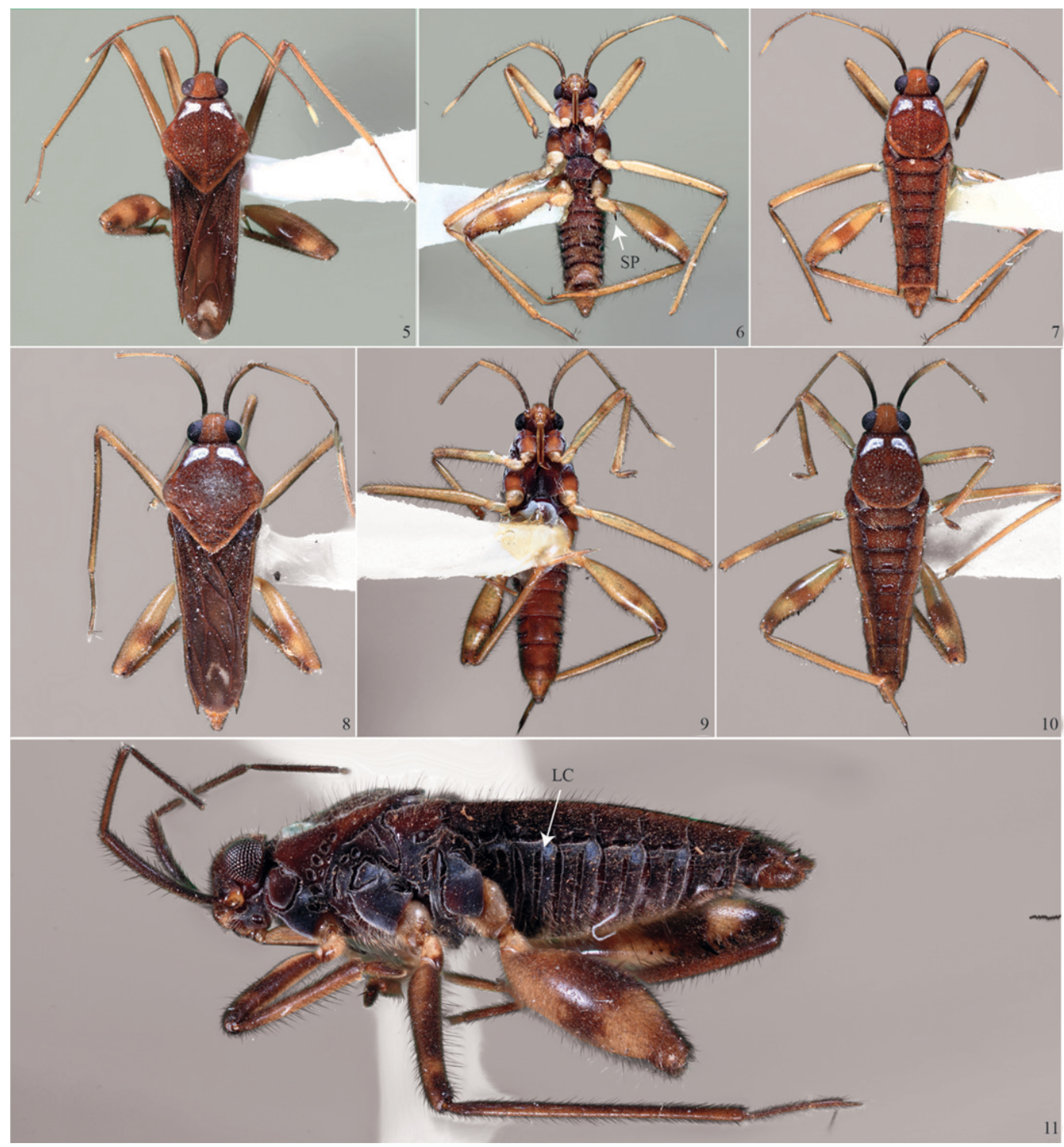

Figs. 5-11. Stridulivelia cinctipes. 5, Macropterous male, dorsal view. 6, Micropterous male, ventral view. 7, Micropterous male, dorsal view. 8, Macropterous female, dorsal view. 9, Micropterous female, ventral view. 10, Micropterous female, dorsal view. 11, Micropterous male, lateral view. LC: transverse lateral sulci on abdominal pleurites; SP: spur.

$368 \backslash$ N. Nieser'; 'Saramaccal Coesewijne Project $\ 3-I I I-70$ SN $368 \backslash 55^{\circ} 25^{\prime} 5^{\circ} 20^{\prime}$.

Diagnosis.-Pronotal humeral angles spinose (Figs. 13, 15, 17, 18); stridulatory structure on outer margin of abdominal connexiva not anteriorly extended towards mesoacetabulum, formed by a row of fine vertical ridges (Fig. 16); first three visible abdominal segments with transverse lateral sulci (Fig. 16); middle tarsus with narrow, falcate claws and setae-like arolia (as in. Fig. 3); male hind trochanter armed with small spinules (as in Fig. 2); hind femur incrassate, about two times wider 


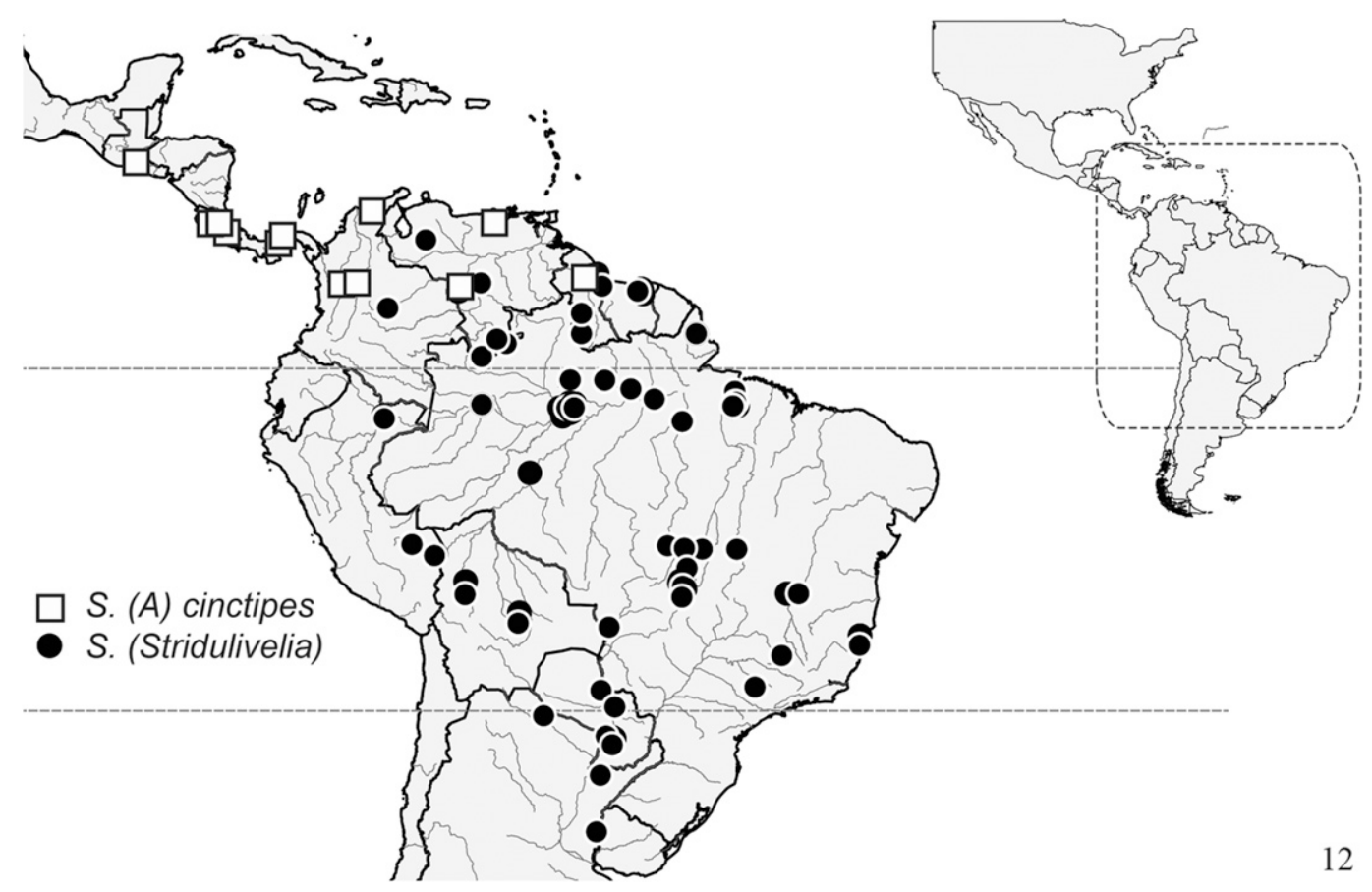

Fig. 12. Map of the geographical distribution of the subgenera Stridulivelia s.str. and Aenictovelia.

than middle femur, with a spine on distal $2 / 3$ of posterior margin distinctly larger than others (Figs. 13, 15); stridulatory structure on dorsum of hind femur small, longer than wide (Fig. 13); last abdominal sternite of male with a pair of lateral projections (Fig. 14); male genital segment I ventrally with posterior margin rounded (Fig. 14); male proctiger with $\mathrm{V}$-shaped anterocentral projection, with width subequal to width of proctiger; paramere with apex slightly acute (Fig. 73); female abdominal tergite VIII with projections, with half the length to as long as segment at midline (Figs. 17, 18).

\section{Stridulivelia (Stridulivelia) anta Polhemus and Spangler, 1995}

(Figs. 2, 3, 19-25, 37, 74)

Stridulivelia (Stridulivelia) anta Polhemus and Spangler 1995: 128,
132, 134-137 (description, illustration, key, map); Moreira et al. 2011b: 22 (distribution, list).

Stridulivelia anta: Dias-Silva et al. 2013a: 135 (ecology).

Material examined.-1우 holotype (NMNH): 'Amazonas\ Igarape Barro Branco nr.\Reserva Ducke HQ, $25 \mathrm{Kml}$ NE Manaus, 50m.I 27 August 1989 CL $2475 \backslash$ D.A. \& J.T. Polhemus'; 'Holotype $\backslash$ Stridulivelia $\backslash$ anta $\backslash$ J.T. Polhemus $\backslash \&$ P. J. Spangler'. 10" paratype (NMNH): 'AmazonasGebiet $\backslash$ nxt. Rio Negro $\backslash$ Agua Encar-\nada\ 27-7-65\ leg. E. J. Fittkau'; 'Paratype\Stridulivelia $\backslash$ anta $\backslash$ Polhemus \& Spangler'. 10" paratype (NMNH): 'AmazonasGebiet\ Rio Marauiál S. Antonio\ 10-1-63\ leg. E. J. Fittkau〉 Coll. Amazonas 1960/3'; 'Paratypel Stridulivelia $\backslash$ anta $\backslash$ Polhemus \& Spangler'. 10 ", 5 우 paratypes (NMNH): 'Brazil, Amazonas Igarape da Anta, Reserva Ducke, 60 m., $24.5^{\circ} \mathrm{C} . \backslash 25$ August 1989 


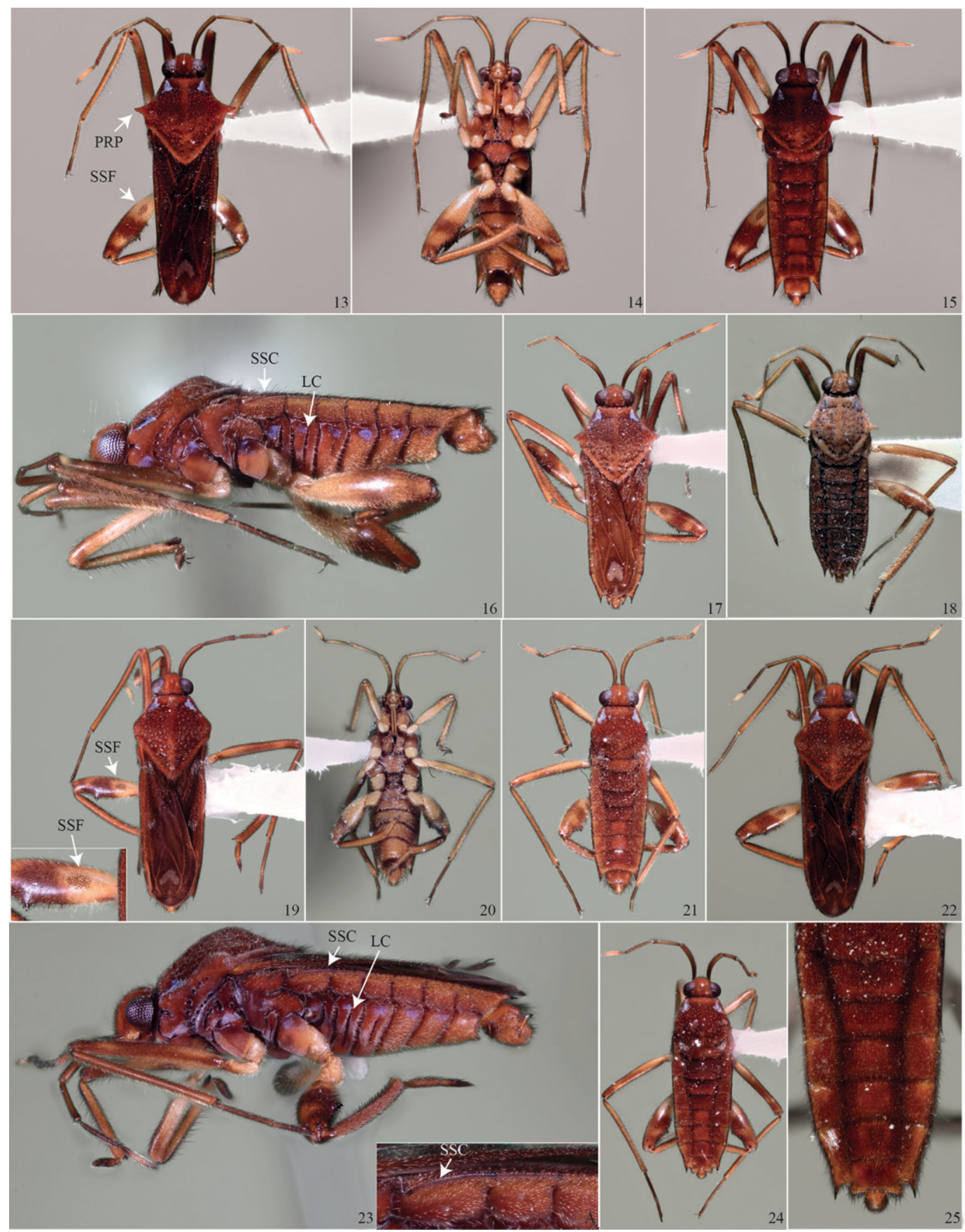

Figs. 13-25. 13-18. Stridulivelia alia. 13, Macropterous male, dorsal view. 14, Apterous male, ventral view. 15, Apterous male, dorsal view. 16, Apterous male, lateral view. 17, Macropterous female, dorsal view. 18, Apterous female, dorsal view. 19-25. Stridulivelia anta. 19, Macropterous male, dorsal view, metathoracic femur. 20, Micropterous male, ventral view. 21, Micropterous male, dorsal view. 22, Macropterous female, dorsal view. 23, Macropterous male, lateral view. 24, Micropterous female, dorsal view. 25, Abdomen, dorsal view, female. LC: transverse lateral sulci on abdominal pleurites; PRP: pronotal humeral angles spinose; SSF: stridulatory structure on femur; SSC: stridulatory structure on connexivum. 
CL $2472 \backslash$ D. A. \& J. T. Polhemus'; 'Paratype \Stridulivelia $\backslash$ anta $\backslash$ Polhemus \& Spangler'. 2 paratypes (NMNH): 'Brazil, Amazonas\ rainforest stream near\ INPA viewing tower $\mathrm{N}$. of Manaus, 90 m.\} 2 9 \text { August } 1 9 8 9 \text { CL 2478\ } D. A. \& J. T. Polhemus'; 'Paratypel Stridulivelia $\backslash$ anta $\backslash$ Polhemus \& Spangler'.

Diagnosis.-Pronotal humeral angles not spinose (Figs. 19, 21, 22, 24); stridulatory structure on outer margin of abdominal connexiva not anteriorly extended towards mesoacetabulum, formed by a row of fine vertical ridges (Fig. 23); first three visible abdominal segments with transverse lateral sulci (Fig. 23); middle tarsus with narrow, falcate claws and setae-like arolia (Fig. 3 ); male hind trochanter unarmed or armed with small spinules (as in Fig. 2); hind femur incrassate, about two times wider than middle femur, with a spine on distal $2 / 3$ of posterior margin distinctly larger than others (Figs. 19-24); stridulatory structure on dorsum of hind femur small, slightly longer than wide (Fig. 19); last abdominal sternite of male with a pair of lateral projections (Figs. 20, 23); male genital segment I ventrally with posterior margin bulged centrally (Fig. 20); male proctiger with anterocentral projection short and undivided, about half as wide as proctiger; paramere long, narrow, with acute apex (Fig. 74); female abdominal tergite VIII without projections (Figs. 24, 25).

\section{Stridulivelia (Stridulivelia) astralis}

(Drake and Harris, 1938)

(Figs. 26-30, 38, 75)

Velia (Stridulivelia) astralis Drake and Harris 1938: 200-201 (description).

Stridulivelia astralis: Polhemus 1976: 509 (Stridulivelia elevated to genus); Mazzucconi and Bachmann 1997: 62 (records); Bachmann 1998: 180 (distribution, list); López-Ruf et al. 2003: 67 (records); Rodrigues et al. 2012: 912 (records); Floriano et al. 2013: 45 (list); Dias-Silva et al. 2013b: 231 (records); Coscarón et al. 2015: 7 (type list).

Stridulivelia (Stridulivelia) astralis:

Polhemus 1979: 46 (subgenus placement); Polhemus and Spangler 1995: 128, 132, 137-138 (diagnosis, key, map, records); Coscarón and Loiácono 1996: 2 (type list); Moreira et al. 2011b: 22 (distribution, list).

Material examined.—2 -20" paratypes (NMNH): 'Mattogrosso'; '43'; 'Paratypel Velia $\backslash$ astralis $\backslash \mathrm{D}$ and $\mathrm{H}$ '; 'C J Drake\ Coll. 1956'; 'Velia $\backslash$ astralis $\backslash \mathrm{D}$ and H'.

Diagnosis.-Pronotal humeral angles not spinose (Figs. 26, 28); stridulatory structure on outer margin of abdominal connexiva anteriorly extended towards mesoacetabulum, formed by a row of tightly packed minute pegs (Fig. 29); first three visible abdominal segments with transverse lateral sulci (Fig. 29); middle tarsus with narrow, falcate claws and setae-like arolia (as in Fig. 3); male hind trochanter unarmed or armed with small spinules (as in Fig 2); hind femur incrassate, about two times wider than middle femur, with a spine on distal $2 / 3$ of posterior margin distinctly larger than others (Figs. 26-28, 30); stridulatory structure on dorsum of hind femur small, rastrate (Fig. 30); last abdominal sternite of male without distinct lateral projections, with small rounded expansions (Figs. 27, 29); male genital segment I ventrally with a central expansion (Fig. 27); male proctiger with anterolateral projection; apically rounded paramere with anterior margin abruptly expanded before middle (Fig. 75); female abdominal tergite VIII without projections (Fig. 28). 


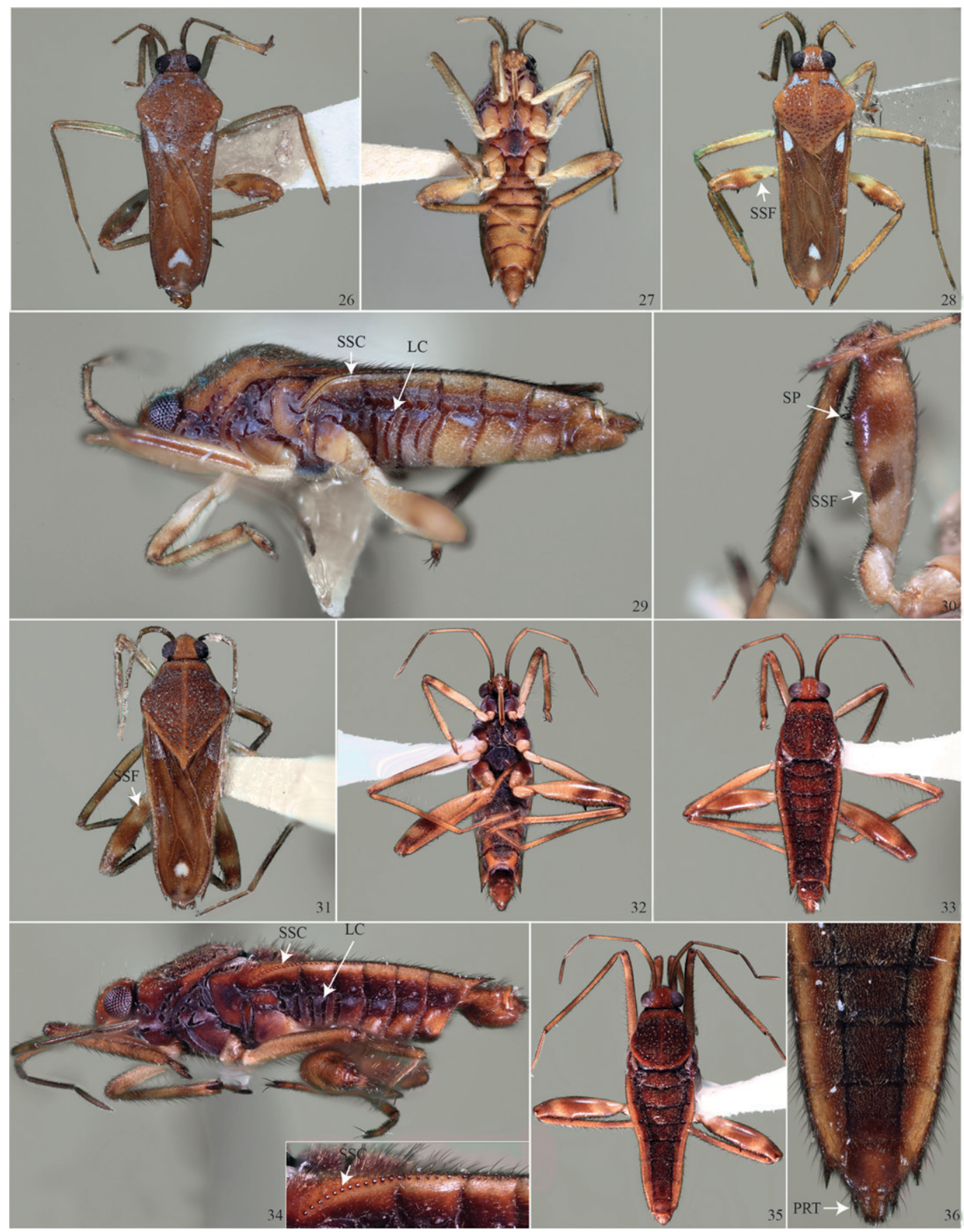

Figs. 26-36. 26-30. Stridulivelia astralis. 26, Macropterous male, dorsal view, paratype. 27, Macropterous male, ventral view, paratype. 28, Macropterous female, dorsal view. 29, Macropterous male, lateral view. 30, Leg, male. 31-36. Stridulivelia ayacucho. 31, Macropterous male, dorsal view, paratype. 32, Micropterous male, ventral view, paratype. 33, Micropterous male, dorsal view, paratype. 34, Micropterous male, lateral view, paratype. 35, Micropterous female, dorsal view, paratype. 36, Abdomen, female. LC: transverse lateral sulci on abdominal pleurites; PRT: projections on tergite VIII; SP: large spine; SSF: stridulatory structure on femur; SSC: stridulatory structure on connexivum. 
Stridulivelia (Stridulivelia) ayacucho Polhemus and Spangler, 1995

(Figs. 31-36, 38, 76)

Stridulivelia (Stridulivelia) ayacucho Polhemus and Spangler 1995: 128, 132, 137-141 (description, illustration, key, map); Moreira et al. 2011b: 23 (distribution, list).

Stridulivelia ayacucho: Bachmann 1998: 180 (distribution, list); Melo and Nieser 2004: 46 (records); Torres et al. 2007: 135 (records); Moreira and Barbosa 2011: 311 (records).

Material examined.-10" holotype (NMNH): 'Venezuela, Amazonas\Missionary Stream $21 \mathrm{~km} . \backslash \mathrm{S}$. of Tobogan junction\22 January 1989 CL 2375 $\backslash$ J. T. Polhemus'; 'Holotypel Stridulivelia\ ayacucho $\backslash$ J. T. Polhemus $\backslash$ and P. J. Spangler'. 20" $0^{\prime \prime}, 7 ㅇ ㅜ$ paratypes (NMNH): 'Venezuela, Amazonas\Missionary Stream $21 \mathrm{~km}$. I S. of Tobogan junction\22 January 1989 CL 2375 $\backslash$ J. T. Polhemus'; 'PARATYPE\ Stridulivelia ayacucho $\backslash$ Polhemus \& Spangler'. 2우 paratypes (NMNH): 'Venezuela\ Puerto ayacucho\ 39 km.s 15-XI-87\ brok., Coll. 4I PSS; RAF'. 30"0', 5우 (NMNH): 'Bolivia: Vel. Pr. Los Fierros\ 143'ㅇ' $60^{\circ} 55^{\prime} \mathrm{W} \backslash 16-24$ Jan, 1998\S. Spector\&S.Ayazama'.

Diagnosis.-Pronotal humeral angles not spinose (Figs. 31, 33, 35); stridulatory structure on outer margin of abdominal connexiva not anteriorly extended towards mesoacetabulum, formed by a row of widely separated knob-like denticles (Fig. 34); first two or three visible abdominal segments with transverse lateral sulci (Fig. 34); middle tarsus with narrow, falcate claws and setae-like arolia (as in Fig. 3); male hind trochanter armed with small spinules (as in Fig. 2); hind femur incrassate, about 2.5 times wider than middle femur, with a spine on distal $2 / 3$ of posterior margin distinctly larger than others (Figs. 31-35); stridulatory structure on dorsum of hind femur long, broad, extending onto its posterior surface (Figs. 33, 35); last abdominal sternite of male without lateral projections (Figs. 32, 34); male genital segment I ventrally at most with a central expansion, but not forming a lobule (Fig. 32); male proctiger with a small V-shaped anterocentral projection, with about $1 / 3$ the basal width of proctiger; paramere with apex acute (Fig. 76); female abdominal tergite VIII with short projections, with about one third of the length of the segment at midline (Figs. $35,36)$.

Note.-Instead of two transverse lateral sulci on the abdomen, which is typical for the species, the specimens from Bolivia we examined have three, the third one being often reduced to a small dot. Except for this characteristic, the Bolivian material is identical to other populations of S. ayacucho.

\section{Stridulivelia (Stridulivelia)}

quadrispinosa (Hungerford, 1929)

$$
\text { (Figs. 39-43, 57, 77) }
$$

\section{Velia (Stridulivelia) quadrispinosa} Hungerford, 1929: 52-53, 56-59 (description, illustration, key).

Stridulivelia quadrispinosa: Polhemus 1976: 509 (Stridulivelia elevated to genus); Bachmann 1998: 180 (distribution, list); Moreira et al. 2010: 2798 (records); Moreira et al. 2012: 158 (records); Rodrigues et al. 2012: 912 (records); Dias-Silva et al. 2013b: 231-232 (map, records).

Stridulivelia (Stridulivelia) quadrispinosa: Polhemus 1979: 46 (subgenus placement); Polhemus and Spangler 1995: 128, 132, 141-142 (diagnosis, key, map, records); Moreira et al. 2011b: 23 (distribution, list). 


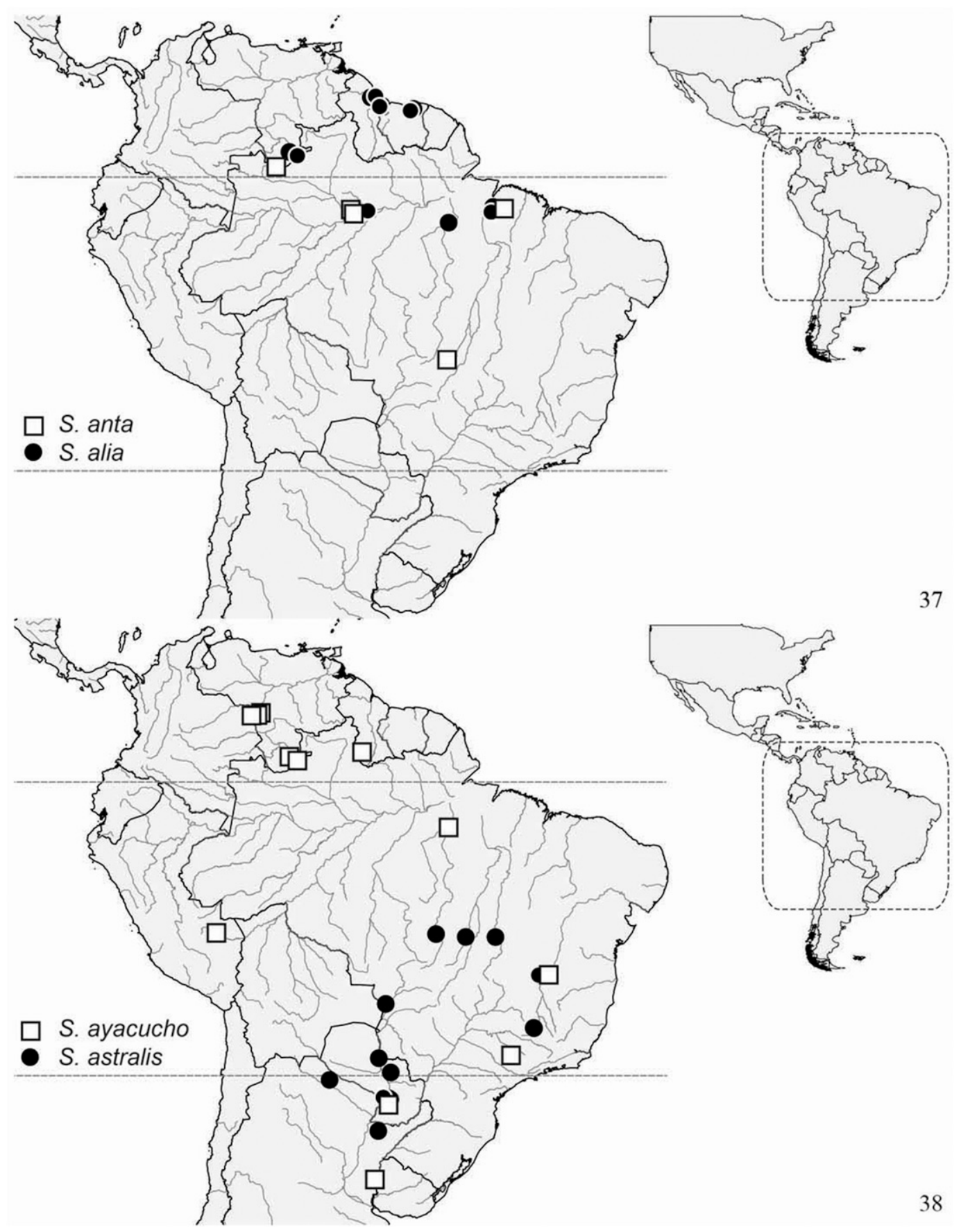

Figs. 37-38. Maps of the geographical distribution. 37, S. alia (black circle) and S. anta (white square). 38, S. astralis (black circle) and S. ayacucho (white square).

Material examined.-20"0", 3우 junction\22 January 1989 CL 2375\ (NMNH): Venezuela, Amazonas $\backslash$ Mis- J.T.Polhemus'. 10" (NMNH): 'Bolivia, sionary Stream, $21 \mathrm{~km} . \backslash \mathrm{S}$. of Tobogan Dept. Beni \rainforest stream $40 \mathrm{~km} . \backslash$ 

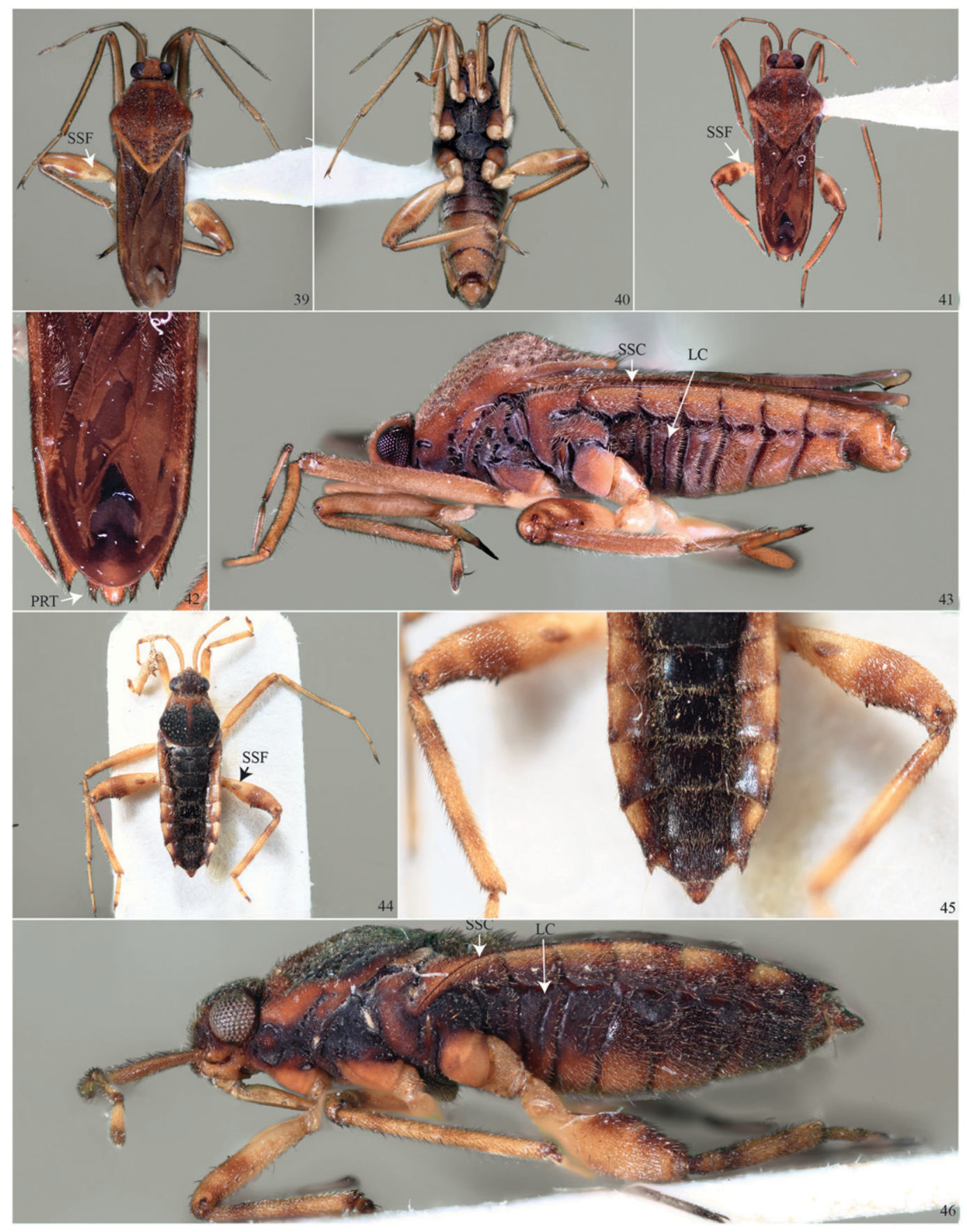

Figs. 39-46. 39-43. Stridulivelia quadrispinosa. 39, Macropterous male, dorsal view. 40, Macropterous male, ventral view. 41, Macropterous female, dorsal view. 42, Abdomen, dorsal view, female. 43, Macropterous male, lateral view. 44-46. Stridulivelia raspa. 44, Micropterous female, dorsal view. 45, Abdomen, dorsal view, female. 46, Micropterous female, lateral view. LC: transverse lateral sulci on abdominal pleurites; PRT: projection on tergite VIII; SSF: stridulatory structure on femur; SSC: stridulatory structure on connexivum. 
S. of Rurrenabaque, near $\backslash$ Monte Redondo sawmill 12 Sept. 1989 CL 2511\350 m. D.A. and J.T. Polhemus'. 100"0", 3 우 (NMNH): 'Venezuela, Amazonas\ small stream $1 \mathrm{~km}$. N. of Alto Mavaca base

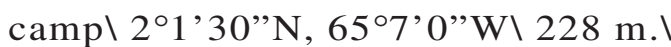
$22^{\circ} \mathrm{C} 4$ Feb. 1989\ CL 8006 D. A. Polhemus'.

Diagnosis.-Pronotal humeral angles not spinose (Figs. 39, 41); stridulatory structure on outer margin of abdominal connexiva not anteriorly extended towards mesoacetabulum, formed by a row of fine vertical ridges (Fig. 43); first three visible abdominal segments with transverse lateral sulci (Fig. 43); middle tarsus with narrow, falcate claws and setae-like arolia (as in Fig. 3); male hind trochanter armed with small spinules (as in Fig. 2); hind femur incrassate, about two times wider than middle femur, with a spine on distal $2 / 3$ of posterior margin distinctly larger than others (Figs. 3941 ); stridulatory structure on dorsum of hind femur small, longer than wide (Fig. $39,41)$; last abdominal sternite of male with a pair of lateral projections (Figs. 40, 43); male genital segment I ventrally with posterior margin bulged centrally (Fig. 40); male proctiger with anterocentral projection half to as wide as proctiger, sometimes subdivided; paramere long, narrow, with rounded apex (Fig. 77); pair of projections on female abdominal tergite VIII, when present, ranging from small lateral expansions to large projections with length subequal to segment (Figs. 41, 42).

Note.-Polhemus and Spangler (1995) evaluated specimens from Beni (Bolivia) and Loreto (Peru), and found variations such as the first genital segment of males more swollen and females without projections on abdominal tergite VIII. They concluded that, except for these characters, the specimens were very similar to those collected in Brazil and Venezuela and belonged to the same species. While studying specimens from Venezuela, we found additional variations, such as the ventral posterior margin of male genital segment I centrally projected and the male proctiger with the anterocentral projection wide and subdivided.

\section{Stridulivelia (Stridulivelia) raspa (Hungerford, 1929)}

(Figs. 44-46, 57, 78)

Velia (Stridulivelia) raspa Hungerford 1929: 51-52, 56-59 (description, illustration, key).

Stridulivelia raspa: Polhemus 1976: 509

(Stridulivelia elevated to genus); Bachmann 1998: 180 (distribution, list); Moreira et al. 2011a: 662 (records); Moreira and Campos 2012: 546 (records).

Stridulivelia (Stridulivelia) raspa:

Polhemus 1979: 46 (subgenus placement); Polhemus and Spangler 1995: 128, 132, 142-143 (diagnosis, key, map, records); Moreira et al. 2011b: 23 (distribution, list).

Material examined.-4우 (USMN): 'Amazonasgebiet $\backslash$ Rio Madeira\ Ig. Tres Casas $\backslash$ 10.11.41\ leg. H. Sioli'; 'Homeotype Velia $\backslash$ raspa Hungerford $\backslash$ Compared with typel by J. T. Polhemus'.

Diagnosis.-Pronotal humeral angles not spinose (Fig. 44); stridulatory structure on outer margin of abdominal connexiva anteriorly extended towards mesoacetabulum, formed by a row of tightly packed minute pegs (Fig. 46); first three visible abdominal segments with transverse lateral sulci (Fig. 46); middle tarsus with narrow, falcate claws and setae-like arolia (as in Fig. 3); hind femur incrassate, about two times wider than middle femur, with a spine on distal $2 / 3$ of posterior margin distinctly larger 
than others (Figs. 44, 45); stridulatory structure on dorsum of hind femur small, rastrate (Figs. 44, 45); paramere with anterior margin sinuous and apex acute (Fig. 78); female abdominal tergite VIII without projections (Figs. 44, 45).

\section{Stridulivelia (Stridulivelia) stridulata} (Hungerford, 1929)

(Figs. 47-51, 58, 79)

Velia (Stridulivelia) stridulata Hungerford, 1929: 53-54, 55-59 (description, illustration, key).

Velia stridulata: Roback and Nieser 1974: 36 (records).

Stridulivelia stridulata: Polhemus 1976: 509 (Stridulivelia elevated to genus); Pereira and Melo 2007: 645 (records); Moreira and Campos 2012: 546-547 (records); Dias-Silva et al. 2013b: 231, 233 (map, records).

Stridulivelia (Stridulivelia) stridulata: Polhemus 1979: 46 (subgenus placement); Polhemus and Spangler 1995: 128, 132, 142-145 (diagnosis, illustration, key, map, records); Moreira et al. 2011b: 23 (distribution, list).

Material examined.-1우 (NMNH): 'Suriname\ VII kreek\10-VII-55'; 'Velia stridulata $\backslash$ allotype\ Hung'. 40" 0 ”, 9우 (NMNH): 'Brazil, Amazonas\ Igarape Barro Branco nr.\ Reserva Ducke HQ, $25 \mathrm{~km}$. NE of Manaus, 50 m. $\backslash 27$ August 1989 CL $2475 \backslash$ D. A. \& J. T. Polhemus'. 3 우우 (NMNH): 'AmazonasGebiet Manaus\IG. Gigante\3-7-64\leg. E.J. Fittkau\Coll. Amazonas 1960/3'. 10" (NMNH): 'Surinam\SN299\N. Nieser Saramacca\ Rd.to S. -Brug\26-I-1976’; 'Stridulivelia $\backslash$ stridulata $\backslash$ Hungfd. $\backslash$ Det. J. T. Polhemus'. 10" (NMNH): 'Suriname SN095\22-VIII-69\N. Nieser'; 'SN095'; 'Zanderijsavannel Carolina Kreek'; 'Stridulivelia $\backslash$ stridulata $\backslash$ Hungerford $\backslash$ Det. JT Polhemus'.
Diagnosis.-Pronotal humeral angles not spinose (Figs. 47, 49); stridulatory structure on outer margin of abdominal connexiva not anteriorly extended towards mesoacetabulum, formed by a row of widely separated knob-like denticles (Fig. 51); first two visible abdominal segments with transverse lateral sulci (Fig. 51); middle tarsus with narrow, falcate claws and setae-like arolia (as in Fig. 3); male hind trochanter armed with small spinules (as in Fig. 2); hind femur incrassate, about 2.5 times wider than middle femur, with a spine on distal $2 / 3$ of posterior margin distinctly larger than others (Figs. 47-49, 51); stridulatory structure on dorsum of hind femur long, broad, extending onto its posterior surface (Fig. 49); last abdominal sternite of male without lateral projections (Figs. $48,51)$; male genital segment I ventrally with a distinct lobule on posterior margin (Fig. 51); male proctiger with a small V-shaped anterocentral projection, with about $1 / 3$ the basal width of proctiger; paramere with apex rounded (Fig. 79); female abdominal tergite VIII with long projections, subequal to the length of the segment at midline (Figs. 49, 50).

Note.-The above mentioned allotype from Suriname is part of the Drake collection in the NMNH. Despite being a historically important specimen, it was collected in 1955, whereas the species was described in 1929. Therefore, it cannot be part of the type series originally studied by Hungerford (1929).

Stridulivelia (Stridulivelia) strigosa (Hungerford, 1929)

(Figs. 52-56, 58, 80)

Velia (Stridulivelia) strigosa Hungerford, 1929: 50-51, 56-59 (description, illustration, key). 


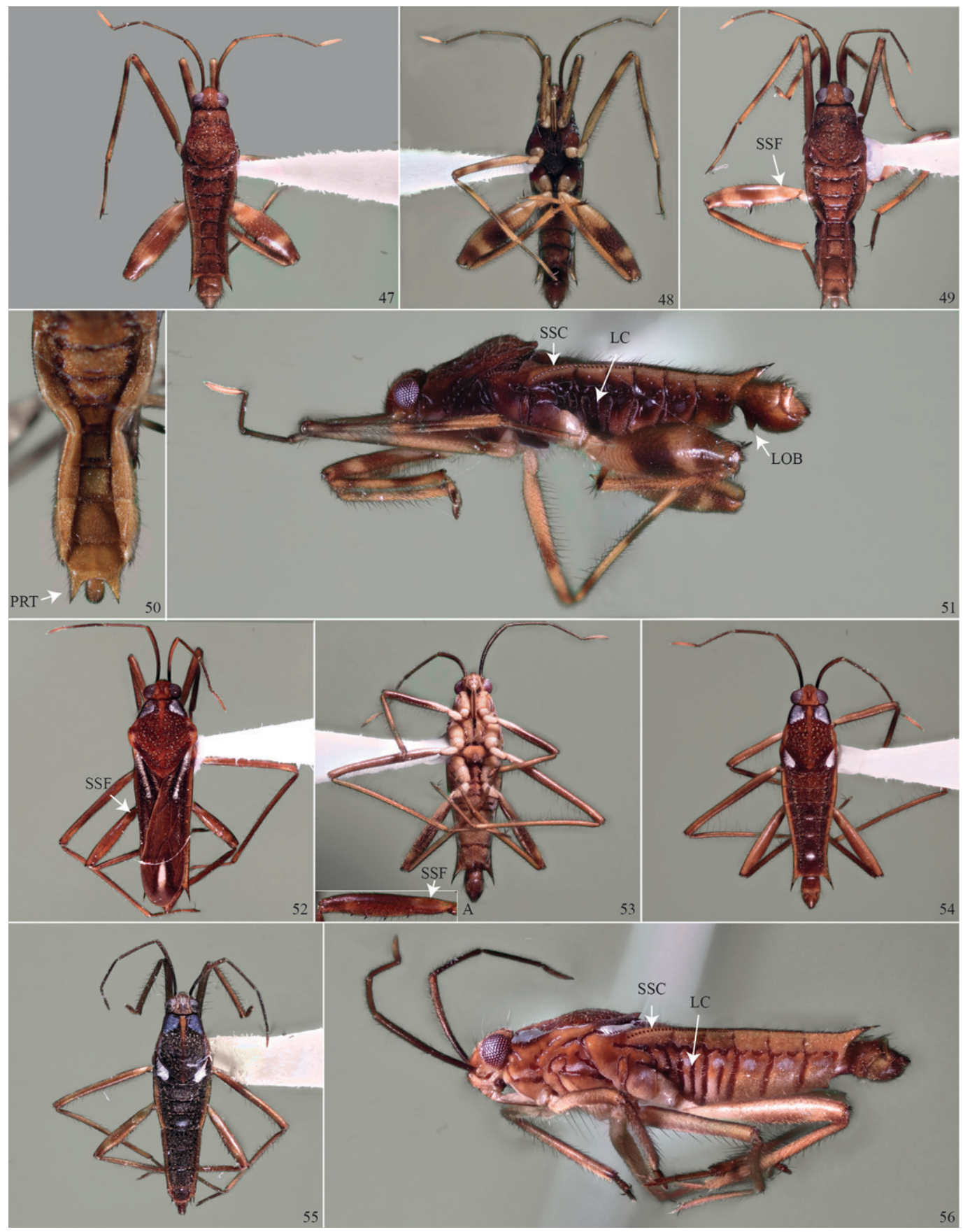

Figs. 47-56. 47-51. Stridulivelia stridulata. 47, Apterous male, dorsal view. 48, Apterous male, ventral view. 49, Micropterous female, dorsal view. 50, Abdomen, dorsal view, female. 51, Apterous male, lateral view. 52-56. Stridulivelia strigosa. 52, Macropterous male, dorsal view. 53, Micropterous male, ventral view, metathoracic femur. 54, Micropterous male, dorsal view. 55, Micropterous female, dorsal view. 56, Micropterous male, lateral view. LOB: lobule on posterior margin of ventrite VIII; LC: transverse lateral sulci on abdominal pleurites; PRT: projection on tergite VIII; SSF: stridulatory structure on femur; SSC: stridulatory structure on connexivum. 
Stridulivelia strigosa: Polhemus 1976: 509 (Stridulivelia elevated to genus); Moreira and Campos 2012: 547 (records); Dias-Silva et al. 2013b: 231 (list); Cordeiro and Moreira 2015: 24 (records); Cunha et al. 2015: 427 (ecology).

Stridulivelia (Stridulivelia) strigosa: Polhemus 1979: 46 (subgenus placement); Polhemus and Spangler 1995: 128, 132, 145-147 (diagnosis, key, map, records); Moreira et al. 2011b: 23 (distribution, list).

Material examined.-230" $0^{\prime \prime}$, 24우 (NMNH): 'Surinam $\backslash$ SN 237 $\backslash$ N. Nieser'; 'Saramaccal 2nd trib. Troelikreek\ XI18-69 SN 237 $55^{\circ} 20^{\prime} / 5^{\circ} 24^{\prime}$. 30' $0^{\prime \prime}, 2$ 우 (NMNH): 'Surinam\SN092\N. Nieser'; 'Zanderijsavannel Carolinakreekl VIII-

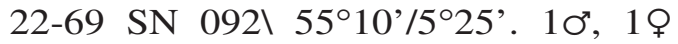
(NMNH): 'Surinam $\backslash$ Rd to Hannover 4 VIII-69 SN 58\N. Nieser'. 10", 1우 (NMNH): 'Surinam,\Zanderijsavannel $1^{\text {st }}$ Tributary of $\backslash$ Colakreek crossing $\backslash$ road to Matta'; '4-IX-1969\S N 116\N. Nieser'. 50" $0^{\prime \prime}, 9$ 9 ㅇ (NMNH): 1st Trib. Colakreek\ 8-IX-69 SN127 55 14' 527'; 'Surinamel SN127 N-Nieser'. 20"0', 3 우 (NMNH): 'Surinamel Carolina-Kreek\8-4-1962\ P. H.v. Doesburg Jr.'; 'Velia tersa Dra $\mathrm{H} \backslash$ det. N. Nieser'. 10" (NMNH): 'Surinam\Zanderij\Savannel 28-VII-69\ Sabakoe-kreek\SN 044\J.T. Polhemus $\backslash$ Collection'; 'Velia strigosa \Hung\ Det. J. T. Polhemus'. $30^{\prime \prime} 0^{\prime \prime}, 4$ 우 (NMNH): 'AmazonasGebiet। Rio Negro\Ig. Barro Br.\30-7-62\ leg. E.J. Fittkau\ Coll. Amazonas 1960/3'. $20^{\circ} \mathrm{O}^{\prime}, 1$ ( $\left.1 \mathrm{NMNH}\right):$ 'Guyana, DubulayRanch $\backslash 5^{\circ} 41^{\circ} 7^{\prime} \mathrm{N} 57^{\circ} 54.6^{\prime} \mathrm{W} \backslash$ leaf packs at edgel Aramatani creek'; 'Collection \#24\15 Apr 1995\ P. J. Spangler'.

Diagnosis.-Pronotal humeral angles not spinose (Figs. 52, 54, 55); stridulatory structure on outer margin of abdominal connexiva not anteriorly extended towards mesoacetabulum, formed by a row of widely separated knob-like denticles (Fig. 56); first three visible abdominal segments with transverse lateral sulci (Fig. 56); middle tarsus with narrow, falcate claws and setae-like arolia (as in Fig. 3); male hind trochanter unarmed or armed with small spinules (as in Fig. 2); hind femur long and slender, about 1.5 times wider than middle femur, without distinctly larger spine on distal 2/3 of posterior margin (Figs. 53-56); stridulatory structure on dorsum of hind femur large, rastrate (Fig. 53); last abdominal sternite of male without lateral projections (Figs. $53,56)$; male genital segment I ventrally with posterior margin rounded (Fig. 53); male proctiger with squareshaped anterocentral projection; paramere with apex rounded (Fig. 80); female abdominal tergite VIII without projections (Fig. 55).

Stridulivelia (Stridulivelia) tersa (Drake and Harris, 1941)

(Figs. 59-64, 71, 81)

Velia (Stridulivelia) tersa Drake and Harris 1941: 338-339 (description); Drake and Menke 1962: 415-416, plate 1 , plate 3 (description of alate forms, illustration, key).

Velia nama Drake: 1957: 114-115 (description). Synonymized by Polhemus and Spangler (1995).

Stridulivelia tersa: Polhemus 1976: 509 (Stridulivelia elevated to genus); Nieser and Alkins-Koo 1991: 51, 64 (distribution, illustration, key, list); Melo and Nieser 2004: 46 (records); Pereira and Melo 2007: 645 (records); Moreira et al. 2010: 2798 (records); Moreira and Campos 2012: 547 (records); Rodrigues et al. 2012: 912 (records); Dias-Silva et al. 2013b: 231-232 (records); Cunha et al. 2015 (ecology). 


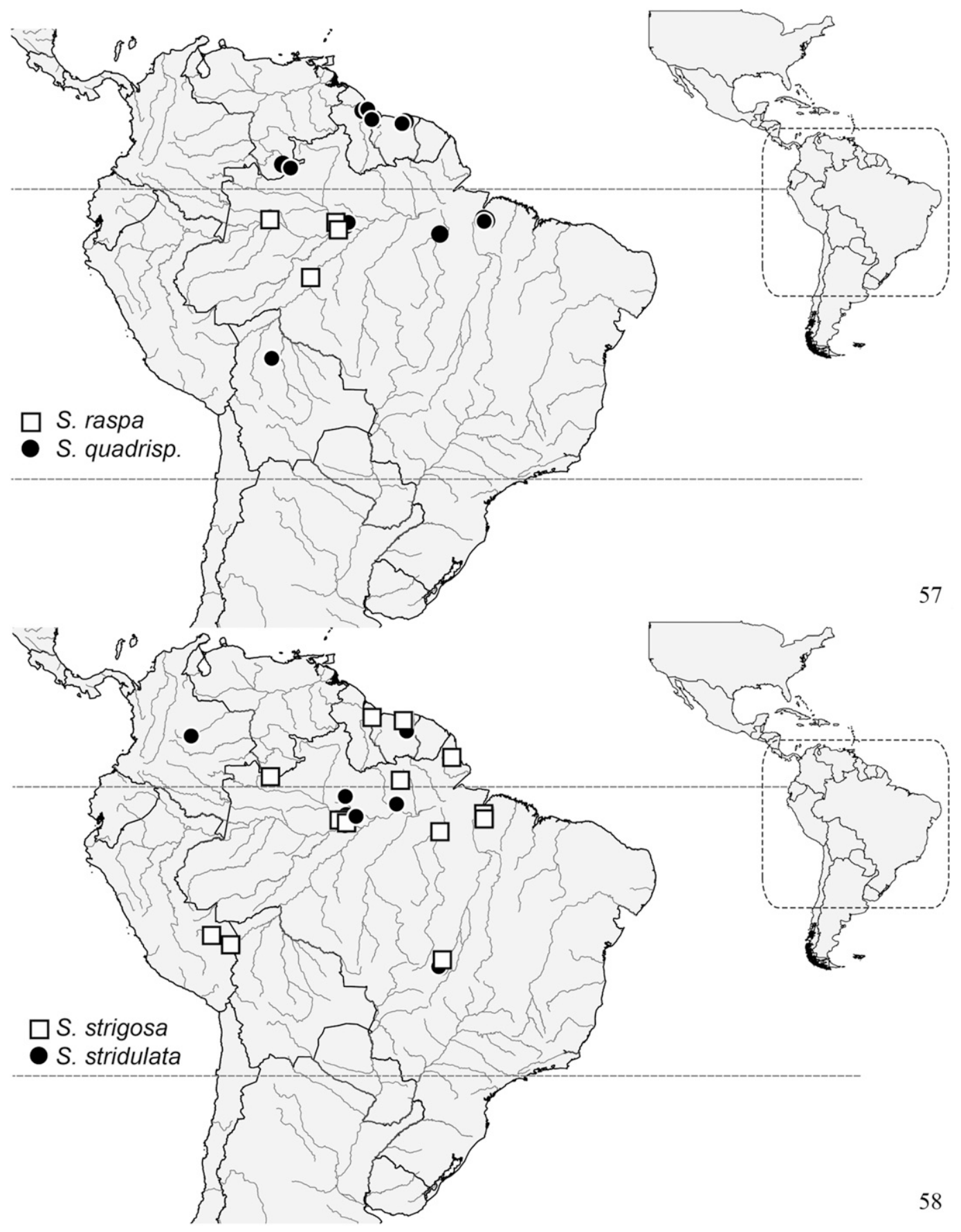

Figs. 57-58. Map of the geographical distribution. 57, S. quadrispinosa (black circle) and S. raspa (white square). 58, S. strigosa (white square) and S. stridulata (black circle).

Stridulivelia (Stridulivelia) tersa: 128, 130-131, 147-150 (diagnosis, ilPolhemus 1979: 46 (subgenus place- $\quad$ lustration, key, map, records); Coscarón ment); Polhemus and Spangler 1995: and Loiácono 1996: 2 (type list); 

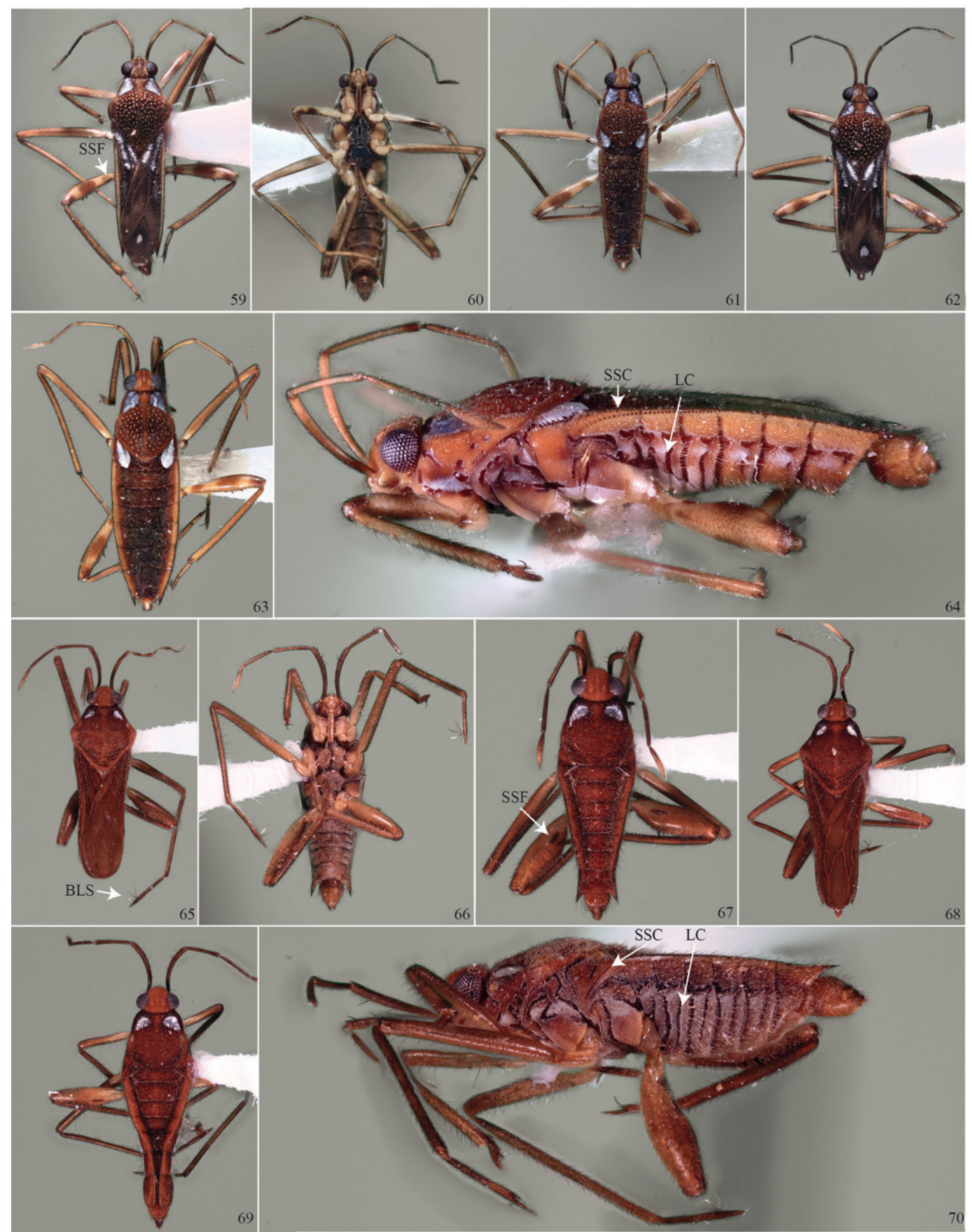

Figs. 59-70. 59-64. Stridulivelia tersa. 59, Macropterous male, dorsal view. 60, Micropterous male, ventral view. 61, Micropterous male, dorsal view. 62, Macropterous female, dorsal view. 63, Micropterous female, dorsal view. 64, Micropterous male, lateral view. 65-70. Stridulivelia transversa. 65, Macropterous male, dorsal view. 66, Apterous male, ventral view. 67, Apterous male, dorsal view. 68, Macropterous female, dorsal view. 69, Apterous female, dorsal view. 70, Apterous male, lateral view. BLS: blade-like claws; LC: transverse lateral sulci on abdominal pleurites; SSF: stridulatory structure on femur; SSC: stridulatory structure on connexivum. 


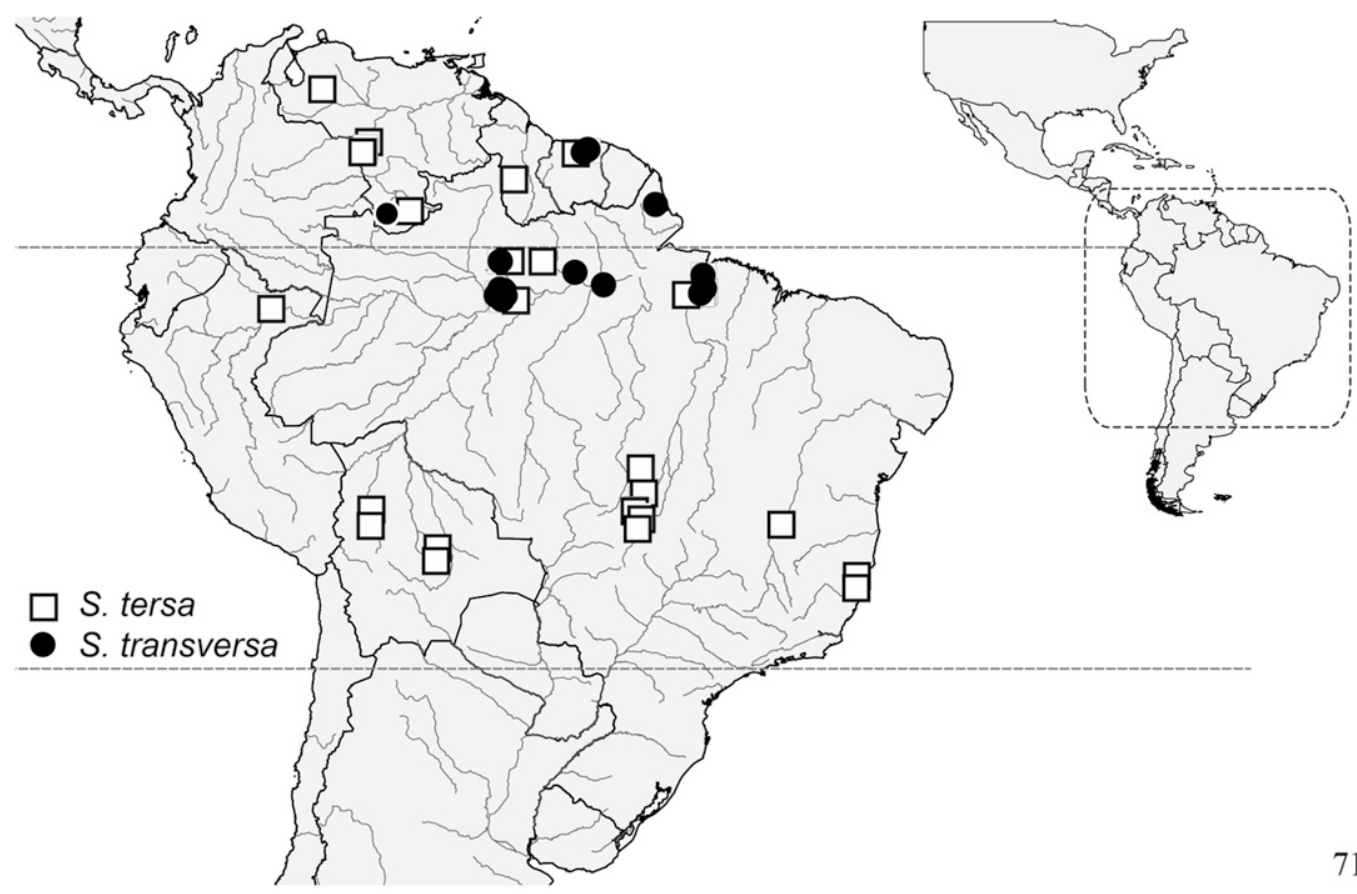

Fig. 71. Map of the geographical distribution of $S$. transversa (black circle) and S. tersa (white square).

Moreira et al. 2011b: 23 (distribution, list); Kment and Kolínová 2013: 861 (type list).

Velia tersa: Coscarón et al. 2015: 7 (type list).

Material examined.-10" holotype 'Trinidad, B. W. I\ Oct. 27-29, 1938। Carl J. Drake'; Holotypel Velia $\backslash$ tersa D\&H'; 'CJDrakel Coll 1956'. 10' holotype 'Cuatro Ojos\ Bolivia'; 'Rio Piray IV-26-1959'; 'Typel Velia $\backslash$ nama Drake' 'CJDrakel Coll 1956'; 'CJDrakel Coll 1956'. 10', 18우 paratypes (NMNH): Trinidad. B. W. I.I Oct. 27-29, 1938। Carl J. Drake'; 'Velia $\backslash$ tersa $\backslash$ D \& H'; 'C J Drakel Coll. 1956'. 10" paratype (NMNH): 'Barinitas $\backslash$ Dec.; 42 Venez $\backslash$ P. Anduzee'; 'V.\tersa $\backslash$ winged'.

Diagnosis.-Pronotal humeral angles not spinose (Figs. 59, 61-63); stridulatory structure on outer margin of abdominal connexiva not anteriorly extended towards mesoacetabulum, formed by a row of widely separated knob-like denticles (Fig. 64); first four or five visible abdominal segments with transverse lateral sulci (Fig. 64); middle tarsus with narrow, falcate claws and setae-like arolia (as in Fig. 3 ); male hind trochanter unarmed or armed with small spinules (as in Fig. 2); hind femur long and slender, about 1.5 times wider than middle femur, without distinctly larger spine on distal 2/3 of posterior margin (Figs. 59-63); stridulatory structure on dorsum of hind femur large, rastrate (Fig. 59); last abdominal sternite of male without lateral projections (Figs. 60, 64); male genital segment I ventrally with posterior margin slightly bulged centrally (Fig. 60); male proctiger without anterocentral projection; paramere with apex rounded (Fig. 81); female abdominal tergite VIII without projections (Figs. $62,63)$. 
Stridulivelia (Stridulivelia) transversa (Hungerford, 1929)

(Figs. 1, 4; 65-70; 71, 82)

Velia (Stridulivelia) transversa Hungerford 1929: 54-55, 57-59 (description, illustration, key).

Stridulivelia transversa: Polhemus 1976: 509 (Stridulivelia elevated to genus); Pereira and Melo 2007: 645 (records); Moreira and Campos 2012: 547 (records); Cordeiro and Moreira 2015: 24-25 (records); Cunha et al. 2015: 427 (ecology).

Stridulivelia (Stridulivelia) transversa: Polhemus 1979: 46 (subgenus placement); Polhemus and Spangler 1995: 128, 131, 150-151 (diagnosis, key, map, records); Moreira et al. 2011b: 23 (distribution, list).

Material examined.-20"0", 9우 (NMNH): 'Venezuela, Amazonas \small stream $1 \mathrm{~km}$. N. of $\backslash$ Alto Mavaca base camp $\backslash 2^{\circ} 1^{\prime} 30^{\prime \prime} \mathrm{N}, 65^{\circ} 7^{\prime} 0^{\prime \prime} \mathrm{W} \backslash 228 \mathrm{~m}$. $22^{\circ} \mathrm{C} 4$ Feb. 1989 CL 8006 D. A. Pohemus'; 'Stridulivelial transversal Hungerford $\backslash$ det. D. Polhemus'. 20"0", 1 우 (NMNH): 'AmazonasGebiet\ Rio Negro\Ig. Barro Branco\Ju.7.62\ leg. E. J. Fittkau Coll. Amazonas 1960/3'. 40"o', 4ㅇ (NMNH): 'Brazil, Amazonas\ Igarape Barro Branco nr. $\backslash$ Reserva Ducke HQ, $25 \mathrm{~km} .1 \mathrm{NE}$ of Manaus, $50 \mathrm{~m} .1$ 27 August 1989, CL 2475\ D.A. \& J.T. Polhemus'.

Diagnosis.-Pronotal humeral angles not spinose (Figs. 65, 67-69); stridulatory structure on outer margin of abdominal connexiva anteriorly extended towards mesoacetabulum, formed by a row of tightly packed minute pegs (Fig. 70); first five visible abdominal segments with transverse lateral sulci (Fig. 70); male sometimes with additional small sulcus on sixth visible segment; middle tarsus with three blade-like structures (modified claws and arolium, Figs. 4, 65); male hind trochanter armed with a spur
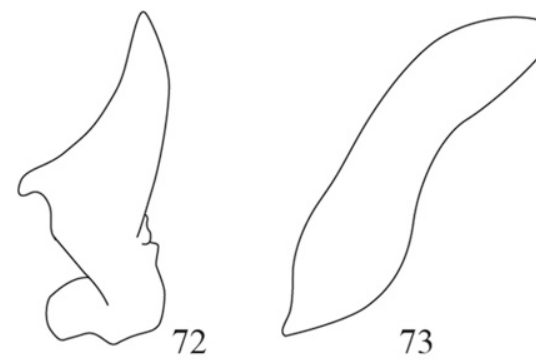

73
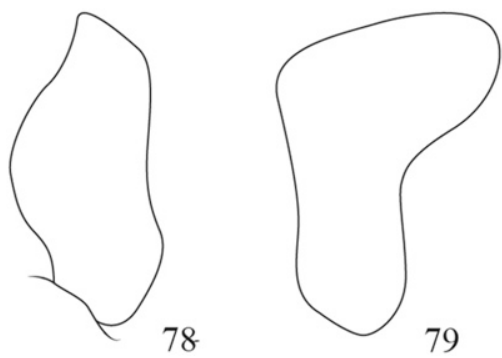

79

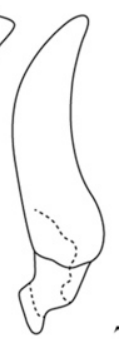

74
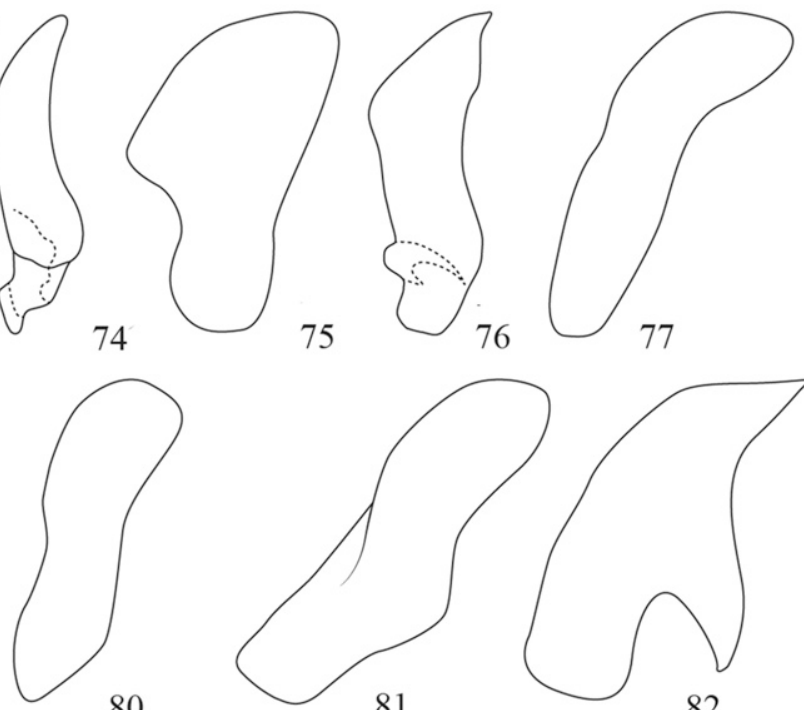

80

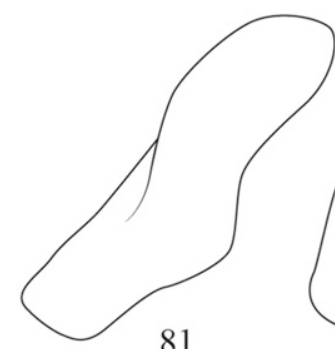

81

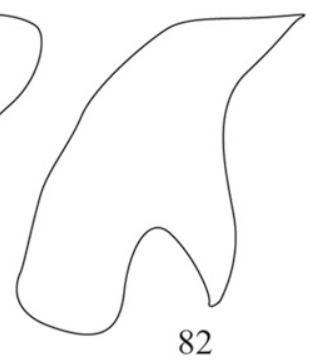

Figs. 72-82. Parameres of Stridulivelia spp. 72, S. cinctipes (modified from Polhemus \& Spangler (1995). 73, S. alia. 74, S. anta (modified from Hungerford (1929)). 75, S. astralis. 76, S. ayacucho (modified from Hungerford (1929)). 77, S. quadrispinosa. 78, S. raspa (modified from Hungerford (1929)). 79, S. stridulata. 80, S. strigosa. 81, S. tersa. 82, S. transversa. 
(Fig. 1); hind femur incrassate, about two times wider than middle femur, with a spine on distal $2 / 3$ of posterior margin distinctly larger than others (Figs. 65$70)$; stridulatory structure on dorsum of hind femur small, about twice as long as wide (Fig. 67); last abdominal sternite of male with small lateral projections (Figs. $66,70)$; male genital segment I ventrally rounded (Fig. 66); male proctiger without anterocentral projection; paramere basally divided into two lobes, with acute apex (Fig. 82); female abdominal tergite VIII without projections (Figs. 68, 69).

Note.-Polhemus (1979) described the subgenus Stridulivelia (Aenictovelia) to accommodate primarily Mesoamerican species that lacked stridulatory structures and had the middle tarsi with blade-like claws and downcurving arolia. Stridulivelia transversa was kept in the nominal subgenus because it bears stridulatory structures; however, it has the same modifications of middle leg pretarsal structures as seen in $S$. (Aenictovelia), which indicates the need for a phylogenetic analysis in order hypothesize its correct placement, as well as determine the monophyly of the two subgenera.

\section{ACKNOWLEDGMENTS}

We thank the National Museum of Natural History, Smithsonian Institution, Washington, D. C., for providing research space and Thomas J. Henry (Systematic Entomology Laboratory, ARS, USDA, c/o NMNH) for providing access to the collections, camera equipment, and the scanning electron microscope for the senior author. The senior author also benefited from a $\mathrm{PhD}$ scholarship provided by the State of São Paulo Research Foundation (number 2013/16367-0 and 2015/09491-2) and
CNPq (National Council for Scientific and Technological Development). PCB thanks CNPq (number 305275/2014-3) for a research fellowship. The Laboratory of Aquatic Biology from UNESP (Assis) is thankful for the support from FAPESP (number 12/21196-8).

\section{Literature Cited}

Allee, W. S. and M. Torvik. 1927. Factors affecting animal distribution in a small stream of the Panama rain-forest in the dry season. The Journal of Ecology 15 (1): 66-71.

Alvarez, L. F. and G. Roldán-Pérez. 1983. Estudio del orden Hemiptera (Heteroptera) en el Departamento de Antioquia en diferentes pisos altitudinales. Actualidades Biológicas 12 (44): 31-45.

Bachmann, A. O. 1998. Heteroptea Acuáticos In Morrone, J. J. and S. Coscarón, eds. Biodiversidad de Artrópodos Argentinos. Una Perspectiva Biotaxonómica. La Plata, Ediciones Sur, 599 pp.

Champion, C. G. (1897-1901). Insecta. Rhynchota. Hemiptera-Heteroptera. Vol. II Biologia Centrali-Americana 2: i-xvi + 1-416+ 22 plates.

Cordeiro, I. R. S. and F. F. F. Moreira. 2015. New distributional data on aquatic and semiaquatic bugs (Hemiptera: Heteroptera: Gerromorpha and Nepomorpha) from South America. Biodiversity Data Journal 3: e4913.

Coscarón, M. C. and M. S. Loiácono. 1996. Los ejemplares tipo de Gerromorpha (Heteroptera) depositados en la colección del Museo de La Plata. Revista del Museo de La Plata, Serie Técnica y Didática 22: 1-5.

Coscarón, M. C., C. Basset, and N. Lopez. 2015. Types of true bugs (Insecta, Hemiptera, Heteroptera) deposited in the Museo de La Plata, Argentina. Zootaxa 3977 (1): 1-101.

Cunha, E. J., L. F. A. Montag, and L. Juen. 2015. Oil palm crops effects on environmental integrity of Amazonian streams and Heteropteran (Hemiptera) species diversity. Ecological Indicators 52: 422-429.

Dias-Silva, K., H. S. R. Cabette, N. F. S. Giehl, and L. Juen. 2013a. Distribuição de Heteroptera aquáticos (Insecta) em diferentes tipos de substratos de córregos do Cerrado matogrossense. Entomobrasilis 6 (2): 132-140.

Dias-Silva, K., F. F. F. Moreira, N. F. S. Giehl, C. C. Nóbrega, and H. S. R. Cabette. 2013 b. 
Gerromorpha (Hemiptera: Heteroptera) of eastern Mato Grosso State, Brazil: checklist, new records, and species distribution modeling. Zootaxa 3736(3): 201-235.

Drake, C. J. 1957. New Neotropical waterstriders (Hemiptera). Proceedings of the Biological Society of Washington 70: 111118.

Drake, C. J. and H. M. Harris. 1938. Veliidae y Gerridae sudamericanos descriptos por Carlos Berg. Notas del Museo de La Plata 3 (Zoología 13): 199-204.

Drake, C. J. and H. M. Harris. 1941. A new Velia from Trinidad (Hemiptera). Revista de Entomologia 12 (1-2): 338-339.

Drake, C. J. and A. S. Menke. 1962. Waterstriders of the subgenus Stridulivelia from Mexico, Central America, and the West Indies (Hemiptera: Veliidae). Proceedings of the United States National Museum 113 (3460): 413-419.

Floriano, C. F. B., I. A. D. V. Oliveira, and A. L. Melo. 2013. New records and checklist of aquatic and semi-aquatic Heteroptera (Insecta: Hemiptera: Gerromorpha and Nepomorpha) from the southern region of Mato Grosso do Sul, Brazil. Biota Neotropica 13 (1): 210-219.

Froeschner, R. C. 1999. True bugs (Heteroptera) Of Panama: A synoptic catalog as a contribution To The Study Of Panamanian Biodiversity. Memoirs of the American Entomological Institute 61: 1-393.

Hungerford, H. B. 1929. Some new semi-aquatic Hemiptera from South America with a record of stridulatory devices. (Veliidae-Velia). Journal of the Kansas Entomological Society 2 (3): 50-59.

Kirkaldy, G. W. and J. R. Torre-Bueno. 1909. A catalogue of American aquatic and semiaquatic Hemiptera. Proceedings of the Entomological Society of Washington 10: 173-213.

Kment, P. and Z. Kolínová. 2013. Catalogue of type specimens of true bugs (Hemiptera: Heteroptera) deposited in the National Museum, Prague, Czech Republic. Acta Entomologica Musei Nationalis Pragae 53 (2): 821-890.

López Ruf, M. L., S. A. Mazzucconi, and A. O. Bachmann. 2003. Heteroptera acuáticos y semiacuáticos del Parque Nacional Mburucuyá (Provincia de Corrientes, Argentina). Revista de la Sociedad Entomológica Argentina 62 (12): 65-71.
Mazzucconi, S. A. and A. O. Bachmann. 1997: Los géneros Oiovelia y Stridulivelia de la Argentina (Heteroptera: Veliidae). Revista de la Sociedad Entomológica Argentina 56 (1-4): 62.

Melo, A. L. and N. Nieser. 2004. Faunistical notes on aquatic Heteroptera of Minas Gerais (Brazil): an annotated list of Gerromorpha and Nepomorpha collected near Januária, MG. Lundiana 5 (1): 43-49.

Moreira, F. F. F. and J. F. Barbosa. 2011. The Veliidae (Hemiptera: Heteroptera: Gerromorpha) from São Paulo State, Brazil: new species, description of the male of Microvelia ioana Drake \& Hottes, 1952, and synonymical and distributional notes. Annales de Limnologie 47 (3): 297-311.

Moreira, F. F. F., J. F. Barbosa, and J. L. Nessimian. 2011a. Description of Microvelia urucara sp. nov. and new distributional data on veliids (Insecta: Heteroptera: Veliidae) from the Amazon River floodplain, Brazil. Zoologia 28 (5): 658-662.

Moreira, F. F. F., J. F. Barbosa, and J. R. I. Ribeiro. 2012. Veliidae (Insecta, Heteroptera, Gerromorpha) from southeastern Brazil: three new species from Rio de Janeiro State, a new species group for Neotropical, Rhagovelia Mayr, and notes on distribution and synonymy. Revista Brasileira de Entomologia 56 (2): 147-158.

Moreira, F. F. F., J. F. Barbosa, J. R. I. Ribeiro, and V. P. Alecrim. 2011b. Checklist and distribution of semiaquatic and aquatic Heteroptera (Gerromorpha and Nepomorpha) occurring in Brazil. Zootaxa 2958: 1-74.

Moreira, F. F. F. and G. G. F. Campos. 2012. New distributional data concerning some Gerromorpha (Insecta: Hemiptera: Heteroptera) from Brazil. Check List 8 (3): 542-547.

Moreira, F. F. F., J. L. Nessimian, J. A. Rúdio, and F. F. Salles. 2010. New species and new records of Veliidae from Espírito Santo and adjacent Minas Gerais State, Brazil, with notes on nomenclature (Insecta: Heteroptera: Veliidae). Journal of Natural History 44 (4546): 2761-2801.

Nieser, N. and M. Alkins-Koo. 1991. The water bugs of Trinidad \& Tobago. Occasional Papers, Zoology Department, University of the West Indies 9: i-iii + 1-127.

Nieser, N. and A. L. Melo. 1997. Os Heterópteros Aquáticos de Minas Gerais - Guia Introdutório com Chave de Identificação para as Espécies de Nepomorpha e Gerromorpha. Belo Horizonte, Editora UFMG, 177 pp. 
Pacheco-Chaves, B., F. F. F. Moreira, and M. Springer. 2014. New records of Gerromorpha (Insecta: Hemiptera: Heteroptera) from Costa Rica. Check List 10 (1): 180-186.

Pereira, D. L. V. and A. L. Melo. 2007. Aquatic and semiaquatic Heteroptera (Insecta) from Pitinga, Amazonas, Brazil. Acta Amazonica 37 (4): 643-648.

Polhemus, J. T. 1976. A reconsideration of the status of the genus Paravelia Breddin, with other notes and a checklist of species (Veliidae: Heteroptera). Journal of the Kansas Entomological Society 49 (4): 509-513.

Polhemus, J. T. 1979. A new species of Stridulivelia from Mexico, and a new subgenus from Middle America (Hemiptera: Veliidae). Pan-Pacific Entomologist 55 (1): 46-50.

Polhemus, J. T. and P. J. Spangler. 1995. A review of the genus Stridulivelia Hungerford and two new species (Heteroptera: Veliidae) from South America. Proceedings of the Enotomological Society of Washington 91 (1): 128-152.

Roback, S. S. and N. Nieser. 1974. Aquatic Hemiptera (Heteroptera) from the Llanos of Colombia. Proceedings of the Academy of Natural Sciences of Philadelphia 126: 29-49.

Rodrigues, H. D. D., A. L. Melo, and R. L. Ferreira-Keppler. 2012. New records of Gerromorpha (Insecta: Hemiptera: Heteroptera) from Brazil. Check List 8 (5): 908-913.

Rodrigues, H. D. D., A. L. Melo, and R. L. Ferreira-Keppler. 2014. Taxonomic revision of the Neotropical genus Oiovelia (Hemiptera: Heteroptera: Veliidae). Acta Entomologica Musei Nationalis Pragae 54 (1): 65-98.

Torres, P. L. M., S. A. Mazzucconi, and M. C. Michat. 2007. Los coleópteros y heterópteros acuáticos del Parque Nacional El Palmar (Provincia de Entre Ríos, Argentina): lista faunística, diversidad y distribución. Revista de la Sociedad Entomologica Argentina 66 (3-4): 127-154. 